\title{
SOEP
}

SOEPpapers

SOEPpapers
on Multidisciplinary Panel Data Research

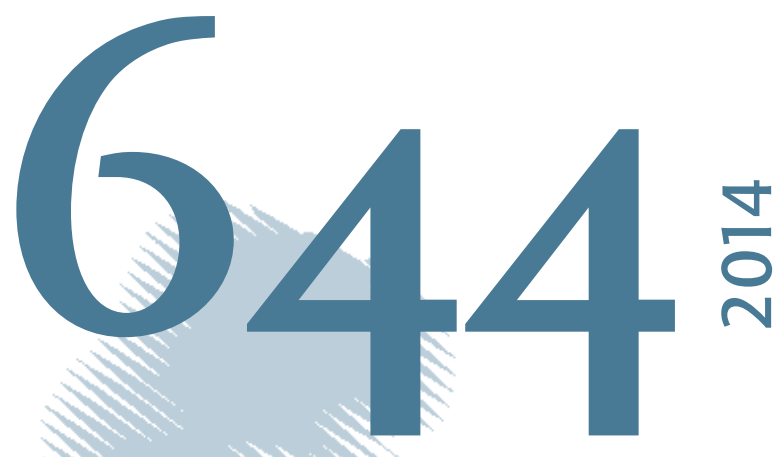

\section{Income Inequality Developments in the Great Recession}




\section{SOEPpapers on Multidisciplinary Panel Data Research}

at DIW Berlin

This series presents research findings based either directly on data from the German SocioEconomic Panel Study (SOEP) or using SOEP data as part of an internationally comparable data set (e.g. CNEF, ECHP, LIS, LWS, CHER/PACO). SOEP is a truly multidisciplinary household panel study covering a wide range of social and behavioral sciences: economics, sociology, psychology, survey methodology, econometrics and applied statistics, educational science, political science, public health, behavioral genetics, demography, geography, and sport science.

The decision to publish a submission in SOEPpapers is made by a board of editors chosen by the DIW Berlin to represent the wide range of disciplines covered by SOEP. There is no external referee process and papers are either accepted or rejected without revision. Papers appear in this series as works in progress and may also appear elsewhere. They often represent preliminary studies and are circulated to encourage discussion. Citation of such a paper should account for its provisional character. A revised version may be requested from the author directly.

Any opinions expressed in this series are those of the author(s) and not those of DIW Berlin. Research disseminated by DIW Berlin may include views on public policy issues, but the institute itself takes no institutional policy positions.

The SOEPpapers are available at

http://www.diw.de/soeppapers

\section{Editors:}

Jürgen Schupp (Sociology)

Gert G. Wagner (Social Sciences, Vice Dean DIW Graduate Center)

Conchita D'Ambrosio (Public Economics)

Denis Gerstorf (Psychology, DIW Research Director)

Elke Holst (Gender Studies, DIW Research Director)

Frauke Kreuter (Survey Methodology, DIW Research Professor)

Martin Kroh (Political Science and Survey Methodology)

Frieder R. Lang (Psychology, DIW Research Professor)

Henning Lohmann (Sociology, DIW Research Professor)

Jörg-Peter Schräpler (Survey Methodology, DIW Research Professor)

Thomas Siedler (Empirical Economics)

C. Katharina Spieß (Empirical Economics and Educational Science)

ISSN: 1864-6689 (online)

German Socio-Economic Panel Study (SOEP)

DIW Berlin

Mohrenstrasse 58

10117 Berlin, Germany

Contact: Uta Rahmann | soeppapers@diw.de 


\title{
Income Inequality Developments in the Great Recession
}

\author{
Tomas Hellebrandt
}

Tomas Hellebrandt, research fellow, has been with the Peterson Institute for International Economics since January 2013. This Policy Brief is part of the Institute's project on inequality and inclusive capitalism, supported by a major grant from the ERANDA Foundation.

Author's note: For comments on an earlier draft, I thank without implicating Anders Åslund, Caroline Freund, Joseph E. Gagnon, Kenneth N. Kuttner, Adam S. Posen, Edwin M. Truman, and Steven R. Weisman.

(C) Peterson Institute for International Economics. All rights reserved.

The Great Recession, which cost tens of millions of jobs, a collapse of asset values around the world, and threatened the global financial system, has generated renewed concern over the long-standing issue of the fairness of the distribution of wealth and income in many societies. Economic inequality has increased in the United States and many other advanced economies over the past 20 to 30 years. This trend generated less worry in the boom years, when unemployment rates were low and cheap credit enabled consumers to borrow and maintain higher standards of living, masking the impact of growing income disparity on consumption patterns and perceptions of well-being.

By reducing household incomes, the global financial crisis has constrained consumption and underscored the diverging fortunes of different groups in society. Popular frustration over growing income disparity and its implications for social cohesion and the quality of democratic processes and institutions has been vigorously expressed in the Occupy Wall Street movement in the United States and similar protest movements in other countries.

Though the general impact of the Great Recession on national incomes in many countries has been clear, the detailed effect on the income distribution has not been studied because of a lack of data. This Policy Brief makes a first effort to provide this analysis by using data on eight advanced economies (Germany, Greece, Ireland, Italy, Slovakia, Spain, the United Kingdom, and United States) between 2007 and 2010. The focus is on the short-run effect of the Great Recession on income inequality with the long-run impact left for future research.

Assessing the drivers of income inequality requires access to detailed microdata on household incomes. The analysis here makes use of the most extensive and comparable such dataset made available for research by the Luxembourg Income Study (LIS) for the years 2007 and 2010 (see appendix A for more details about LIS data). The analysis starts by looking only at inequality in labor income and only among people who are employed. It then progressively expands the income concept by including other sources of income and expands the coverage to include all workingage individuals and their families. The purpose of this selective analysis is to isolate the effect of such particular factors as changes in the employment rate or changes in redistribution within the household or by the state on income inequality.

The results show considerable diversity in the effect of the Great Recession on income inequality in different countries and the ability of families and the state to mitigate its impact through redistribution within households and through public benefit programs and the tax system. In general the effect of the Great Recession on the distribution of earnings among those who remain employed appears to have been limited in most countries in the sample. When 
the nonemployed are included in the analysis, the rise in earnings inequality is much larger, particularly in those countries that saw large falls in employment between 2007 and 2010.

Greater redistribution within households-where household members share the earnings of those who remain in employment-relative to the continuation of the precrisis trend has somewhat mitigated the effect of the Great Recession on earnings inequality. With a few exceptions, government policies-the social safety net and direct taxes-have achieved a much larger mitigating effect on income disparities, with inequality in disposable incomes little changed between 2007 and 2010 in most countries. The marginal impact of means-tested social assistance benefits in mitigating the rise in inequality has been larger than that of work-related social insurance programs. Existing direct taxes have tended to have an equalizing effect in most countries. The analysis also illustrates the point that increasing direct taxes can contribute to reducing inequality, while tax cuts tend to make the distribution of disposable incomes more unequal.

The analysis points to a number of important implications for policy efforts to mitigate the impact of economic downturns on income disparities. It underscores the importance of policies designed to share the burden of adjustment more equally among workers and to reduce the impact of a negative economic shock on employment. It also suggests that policies to increase female employment can enhance the resilience of household finances in recessions, helping to reduce the rise in earnings inequality. And it highlights the importance for equity and fairness of the precise nature of the fiscal policy mix in targeting a particular macroeconomic objective, such as stimulating the economy or consolidating public finances, because different measures can have very different distributive effects.

\section{THE GINI INDEX AS A MEASURE OF INCOME INEQUALITY}

The analysis presented here makes extensive use of the Gini index to capture income inequality. The Gini index is derived from the Lorenz curve, which plots the proportion of the total income of the population ( $y$-axis) that is cumulatively earned by the bottom $x$ percent of the population (figure 1). The Gini index is equal to the ratio of the area between the Lorenz curve and the line of perfect equality $(G)$ to the area of the triangle ABC. It takes values between 0 and 1 (or 100 when expressed as a percentage). Perfect equality is achieved when the bottom $x$ percent of the population receives $x$ percent of total income, in which case the Lorenz curve lies on top of the line of perfect equality and the Gini index is equal to 0 . Perfect inequality is achieved when all income goes to one person, in which case the Lorenz curve is given by the line ABC and the Gini index is equal to 1 (or 100). ${ }^{1}$

The Gini index is the best known and most widely used measure of inequality. This fact, together with its amenability to some useful decompositions, has motivated its use here. Nevertheless, it is important to note that the Gini index is by no means an ideal measure of inequality (see for example F. A. Cowell 2011). The LIS microdata do allow one to explore many alternative measures of inequality, and we leave this worthwhile task for future work.

\footnotetext{
${ }^{1}$. The Gini index can also be described another way, as half of the average difference in income between every pair of units in the population, expressed as a percentage of mean income.
} 
Figure 1: Lorenz curves and the Gini index

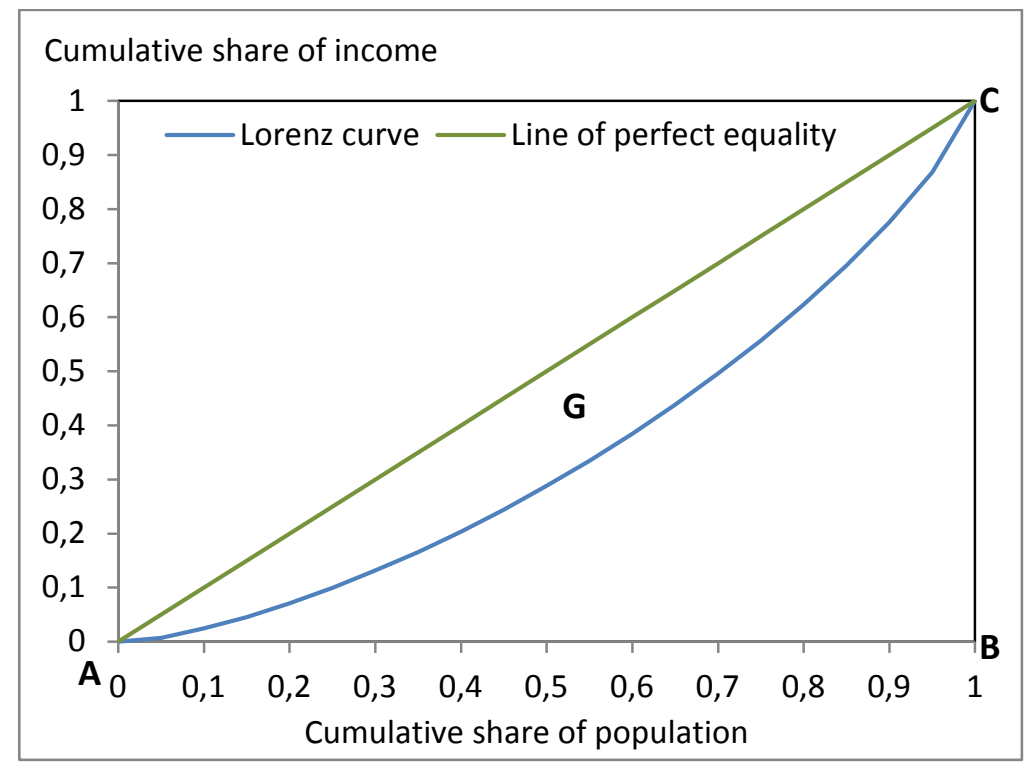

\section{INEQUALITY OF EARNINGS AMONG THE EMPLOYED}

The rise in nonemployment seen in many countries during the Great Recession might be expected to have affected the distribution of pre-tax earnings, or labor income, of the employed to the extent that the labor market upheavals affected different types of workers in different parts of the earnings distribution in varying ways. For example, if employment loss is concentrated among low-paid workers, then all other things being equal, the lower tail of the earnings distribution will shrink, and the inequality of earnings among those left employed will fall. In addition to such compositional changes due to the differential incidence of redundancies, the distribution of earnings will be affected by a multitude of employers' decisions about pay growth and the success or otherwise of the self-employed in making a profit and the impact of these factors at different points of the earnings distribution.

The Gini index on the earnings of employed working-age individuals (15-64 years old) in the sample of countries on the brink of the Great Recession ranged from 33 in Slovakia to 47 in the United States. ${ }^{2}$ The impact of the Great Recession on earnings inequality can be assessed by looking at the change in the Gini index between 2007 and 2010, in absolute terms and relative to the continuation of the precrisis trend ${ }^{3}$ (figure 2). With the exception of Greece ${ }^{4}$ the absolute change has been modest in all countries in the sample. In most cases the changes seen between 2007 and 2010 represent a reversal of the precrisis trends-countries where earnings inequality among the employed was rising before the crisis saw a decline after 2007 (Greece, Ireland, and Germany ${ }^{5}$ ), while those countries where inequality had been falling saw an increase (Spain, the United States, and Slovakia).

\footnotetext{
${ }^{2}$. The Gini index for Italy was 30, but the Italian data on the components of total income, including labor income, are based on net income after income tax and social security contributions and so are not directly comparable to data for the other countries, which are in gross terms.

${ }^{3}$. To the extent that precrisis trends were related in some countries to asset price booms or bubbles, they may not have been sustainable. Assessing the sustainability of precrisis trends in inequality is beyond the scope of this analysis.

${ }^{4}$. The results for Greece should be interpreted with caution given that LIS data has a much higher estimate of the fall in employment in Greece compared to official Labor Force Survey data. See appendix A for more details.

${ }^{5}$. The LIS data for Germany are based on the German Socio-Economic Panel Study (SOEP).
} 
The large fall in earnings inequality in Greece was driven by a fall in the inequality in the distribution of Greek wages, and in particular a considerable shrinking of the upper tail of the wage distribution. Looking at the industry composition of top wage earners in Greece reveals that the shrinking upper tail reflected a large fall between 2007 and 2010 of public sector employees among the top wage earners in Greece. This is probably a result of the significant nominal wage cuts, estimated at 14 percent, that the Greek government implemented in early $2010 .^{6}$ If this is the case, it suggests that not all fiscal consolidation measures need to exacerbate income inequality. Consolidation measures and structural reforms aimed at removing the special privileges of certain professions and sectors can on balance contribute towards equality of incomes.

Figure 2: Change in the Gini index for earnings among the employed, 2007-10

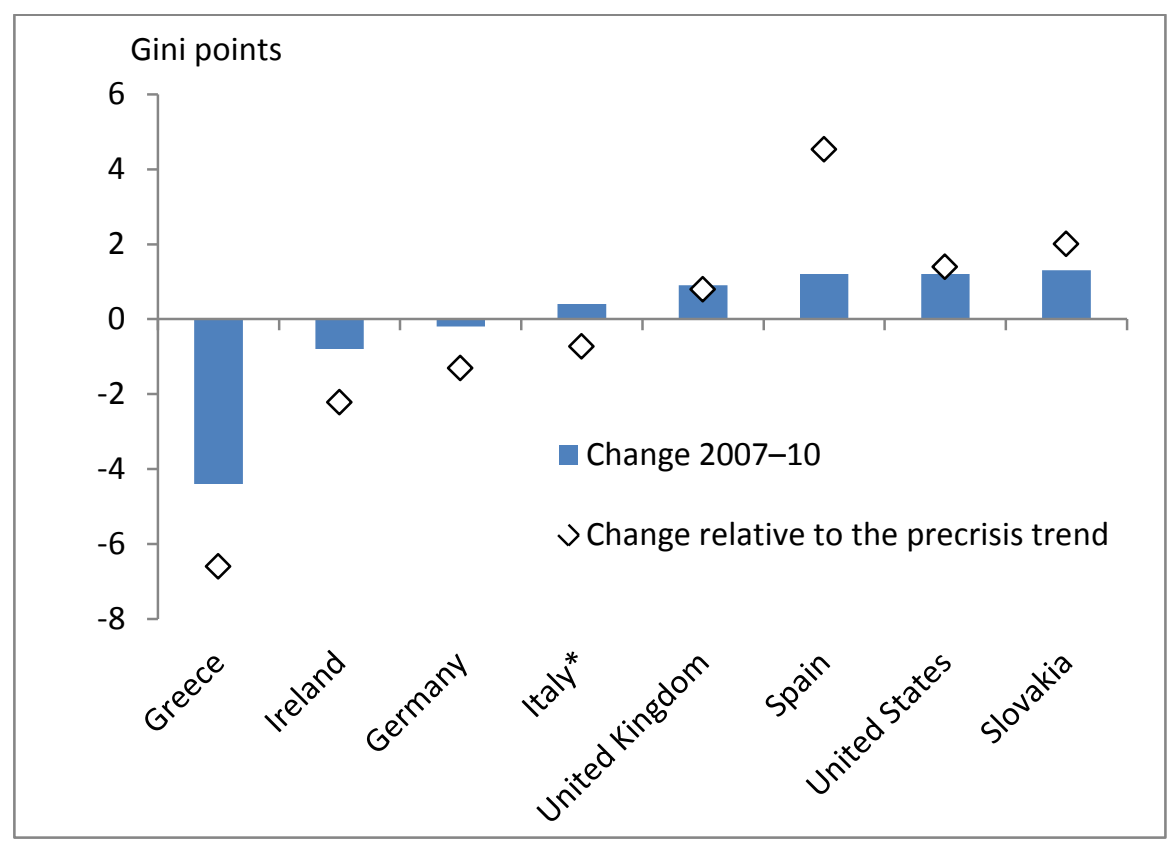

* Italy data are for 2008-10 and are net of tax and social security contributions in contrast to the data for other countries, which are in gross terms

Note: The precrisis trend is calculated over the 2000-2007 period using three data points, except for Italy (2000-08, three data points), the United Kingdom (1999-2007, three data points), and Slovakia (2004-07, two data points).

Source: Luxembourg Income Study Database, 1999-2010, http://www.lisdatacenter.org

\section{INEQUALITY OF EARNINGS AMONG WORKING-AGE INDIVIDUALS}

To assess the direct impact on earnings inequality of the rise in unemployment brought about by the Great Recession, the sample is expanded from earners to all working-age individuals (15-64 years old), including those that are unemployed or inactive. To assess how the earnings inequality among the employed and changes in the employment rate separately contribute to changes in earnings inequality among the working-age population, this analysis makes use of a method of decomposing the Gini index based on a model by A. B. Atkinson and A. Brandolini (2006) and used in OECD (2011a). This decomposition makes use of the fact that the earnings of the nonemployed should be zero. The Lorenz curve is then horizontal over the portion of the population that is nonemployed, and changes in the Gini coefficient can be decomposed into a contribution coming from the change in

${ }^{6}$. Hellenic Stability and Growth Programme Newsletter, Ministry of Finance, May 2010. 
the horizontal portion of the curve and that coming from changes in the curvature of the Lorenz curve for those in employment (i.e., those with positive wages). ${ }^{7}$

The blue bars in figure 3 show the contribution of wage dispersion and reflect the results discussed in the previous section. The red bars show the contribution of changes in the employment rate. The green bar represents the discrepancy between the sum of the contributions of wages and employment and the actual change in the Gini coefficient. This "error" term is due to the fact that some self-employed households report negative earnings-those that have incurred losses in their business over the reporting period. For the purpose of this decomposition, their earnings had to be set to zero, which leads to a small discrepancy.

Figure 3: Change in the Gini index for earnings among the working age population, 2007-10

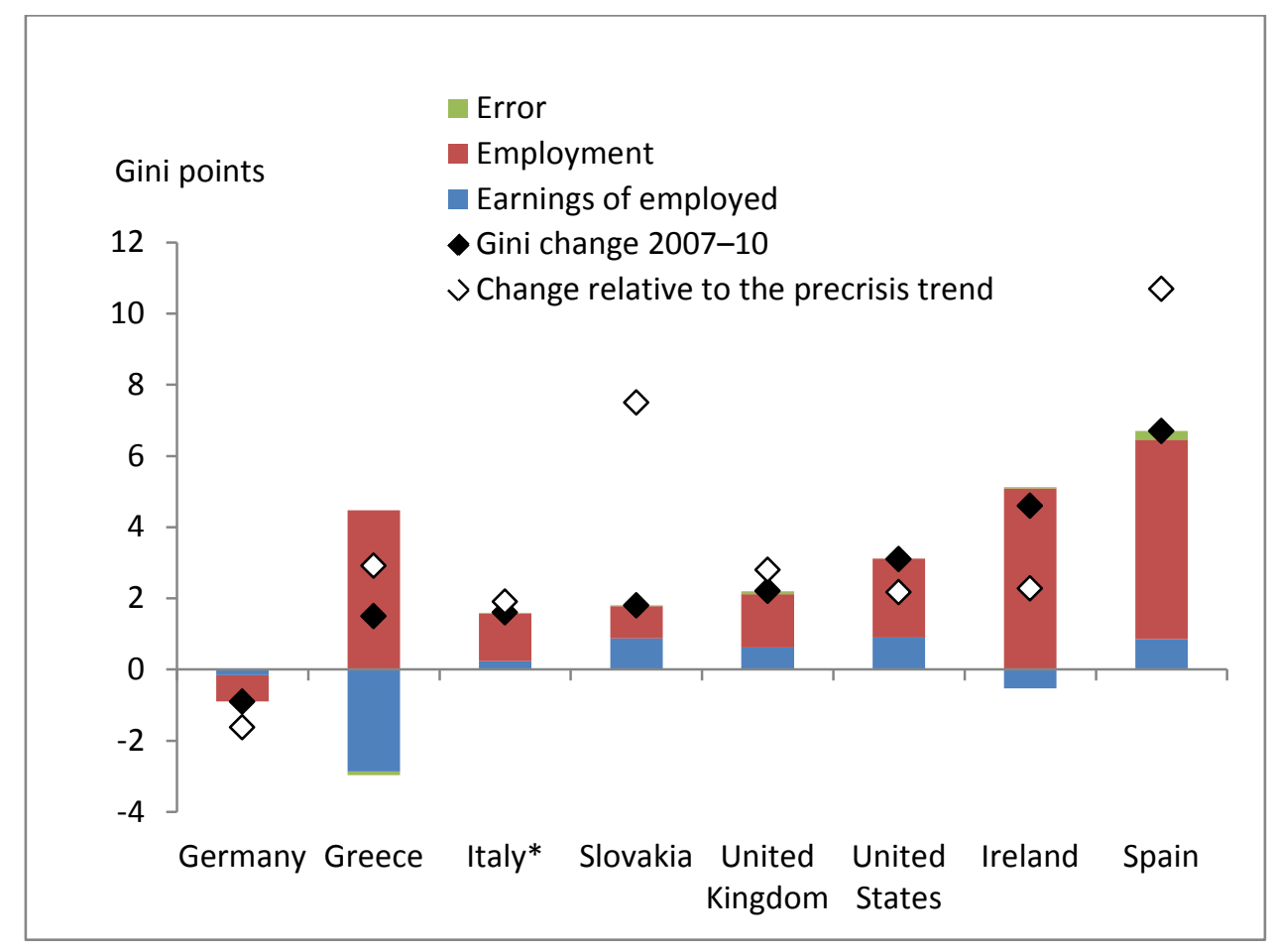

* Italy data are for 2008-10 and are net of tax and social security contributions in contrast to the data for other countries, which are in gross terms

Note: The precrisis trend is calculated over the 2000-2007 period using three data points, except for Italy (2000-08, three data points), the United Kingdom (1999-2007, three data points), and Slovakia (2004-07, two data points).

Source: Luxembourg Income Study Database, 1999-2010, http://www.lisdatacenter.org

The results are not surprising. Rising unemployment has been the key driver of rising earnings inequality amongst working-age individuals in all economies in the sample. In some countries the resulting increase in earnings inequality among the working-age population has been significant. To put these changes into context, using a larger sample of 20 advanced economies around the mid-2000s, the Gini index on earnings among the working-age population ranged from around 50 in Denmark, Norway, and Sweden to 61 in the United States and 64 in Ireland. So an increase of two Gini points is roughly a fifth of the way from Denmark to the United States.

\footnotetext{
${ }^{7}$. Formally, the change in the Gini index can be decomposed as follows: $\Delta \operatorname{Gini}_{\text {all }}=e \Delta$ gini $_{\text {emp }}-\left(1-\right.$ gini $\left._{\text {emp }}\right) \Delta e$ where $e$ is the employment rate at the start, $\Delta$ gini $_{\text {emp }}$ is the change in the Gini coefficient on the incomes of the employed, gini' ${ }_{e m p}$ is the Gini coefficient on the incomes of the employed at the end, and $\Delta e$ is the change in the employment rate.
} 
Clearly, developments in employment matter greatly for inequality outcomes, and policies designed to reduce the impact of a negative economic shock on unemployment can go a long way to mitigating the rise in earnings inequality in a recession.

Germany is a case in point. Despite seeing a larger reduction in real GDP than the United States in the Great Recession, the employment rate among the working-age population rose in Germany between 2007 and 2010 by 2 percentage points, while in the United States it fell by 5 percentage points in the same period. Although the German export-led model placed it in a good position relative to other advanced economies to weather the Great Recession, there is little doubt that employment held up also partly due to government policies. The so-called kurzarbeit policy provided wage subsidies to employees on reduced working hours, thereby preserving their purchasing power and enabling German firms to spread the impact of lower demand and required labor input broadly across all workers rather than to increase unemployment. Though there may be costs to such policies in terms of slowing needed rebalancing in the economy in the face of shifting sectoral demand patterns, the prevention of a significant rise in earnings inequality from increased unemployment is an important benefit.

Ultimately though, in assessing inequality in living standards across countries, we are interested not in gross earnings but in total income, including social transfers and net of tax. Moreover, we want to recognize that significant redistribution happens within households as family members share common resources. The family and the state therefore offer some scope to mitigate the increase in inequality of individual earnings seen in many countries during the Great Recession.

\section{THE ROLE OF HOUSEHOLDS IN MITIGATING THE IMPACT OF THE GREAT RECESSION ON INEQUALITY}

The easiest way to assess the role of the family, or household, in mitigating the increase in earnings inequality during the Great Recession is to see whether the equalizing effect of aggregating individuals into households has increased or decreased between 2007 and 2010. To isolate the role of the family, the income concept in this section remains defined as labor income. The analysis is restricted to families headed by an individual of working-age. The unit of analysis remains the individual, but it is assumed that redistribution within the household takes the form of pooling individual incomes and sharing them equally among household members.

When considering the sharing of resources within households, it is important to recognize that economies of scale, such as sharing the cost of rent and utility bills, mean that a household consisting of two adults needs less than twice the income of a single person to attain the same standard of living. The standard way of making adjustment for household size is to use an equivalence scale that calculates individuals' incomes as total household income divided by the square root of the household size. ${ }^{8}$ The resulting income concept is called equivalized income.

Inequality in equivalized earnings was significantly lower than inequality in individual earnings in all countries in the sample in 2007. The gap ranges from 12 Gini points in the United Kingdom to 22 in Greece. Given the assumption of income sharing, the redistributive role of the family is greater by definition in larger households with more unequal distribution of earnings of household members. Thus differences between countries are related to factors such as average household size, female labor force participation, the gender pay gap, and so-called assortative mating (where high-earning men and women tend to marry each other).

To assess changes in the degree of redistribution within households during the Great Recession, figure 4 shows how the gap has changed between 2007 and 2010, both in absolute terms and relative to the continuation of the precrisis

${ }^{8}$. The adjustment implies that each individual within a family of four on an income of $\$ 60,000$ is equivalent to a single person on an income of $\$ 30,000$. 
trend. It suggests that the redistributive role of the family has not increased very much in absolute terms in most countries, though it fell significantly in Ireland.

However, the change appears much greater in Spain, Slovakia, Greece, and Italy when expressed relative to the continuation of the precrisis trend. The Great Recession appears to have halted a trend of falling redistribution within households in these countries, which was driven by increasing female employment and falling average household size before the crisis. ${ }^{9}$ If this trend had continued during the Great Recession, as it has in Ireland, the rise in inequality in equivalized earnings would have considerably exceeded the rise in inequality in individual earnings shown in figure 3.

Figure 4: Change in the impact of aggregating individuals into households on income inequality, 2007-10

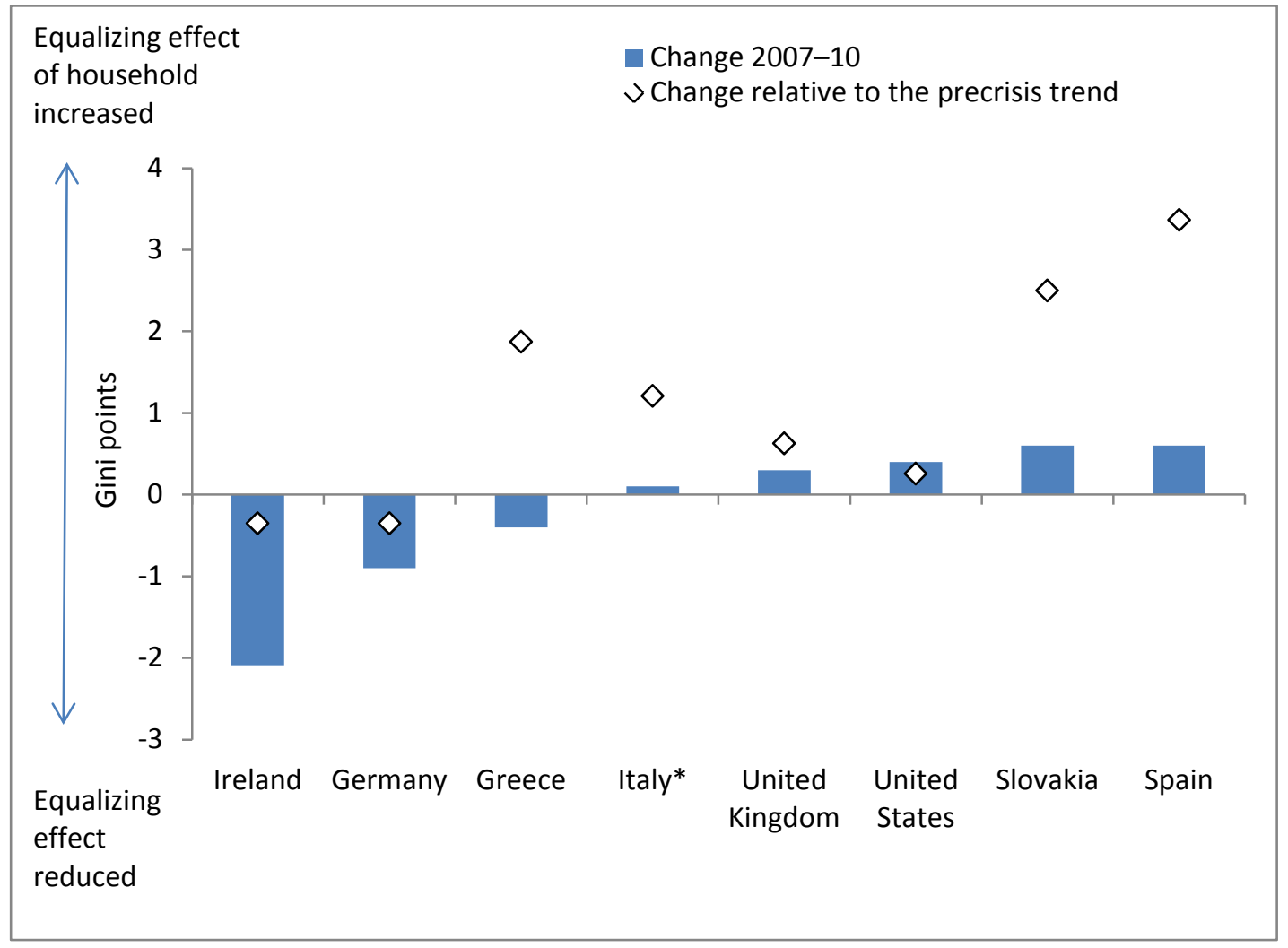

* Italy data are for 2008-10 and are net of tax and social security contributions in contrast to the data for other countries, which are in gross terms

Note: The precrisis trend is calculated over the 2000-2007 period using three data points, except for Italy (2000-08, three data points), the United Kingdom (1999-2007, three data points), and Slovakia (2004-07, two data points).

Source: Luxembourg Income Study Database, 1999-2010, http://www.lisdatacenter.org

It is important to note that the ability of households to mitigate the effect of rising unemployment on inequality is greater in larger households and when more household members work. For example, when one member of a twoearner household loses his or her job, the impact on aggregate inequality in equivalized earnings is lower than when

${ }^{9}$. Note that increased female employment reduces inequality in the aggregate. See for example S. Harkness (2013). However, because female employment tends to lower earnings inequality within households, it reduces the amount of redistribution within households when earnings of household members are shared. 
the sole breadwinner is made redundant, because in the former case the earnings of the remaining employed household member can be shared. This is what seems to have happened in the recession to many households in Spain and Slovakia and to a lesser extent in some of the other countries (figure 5). The rise in the share of single breadwinner households, ${ }^{10}$ relative to trend, is positively related to the change in redistribution within households relative to trend.

Figure 5: Changes in equalizing effect of households and share of single breadwinner households compared, relative to precrisis trend, 2007-10

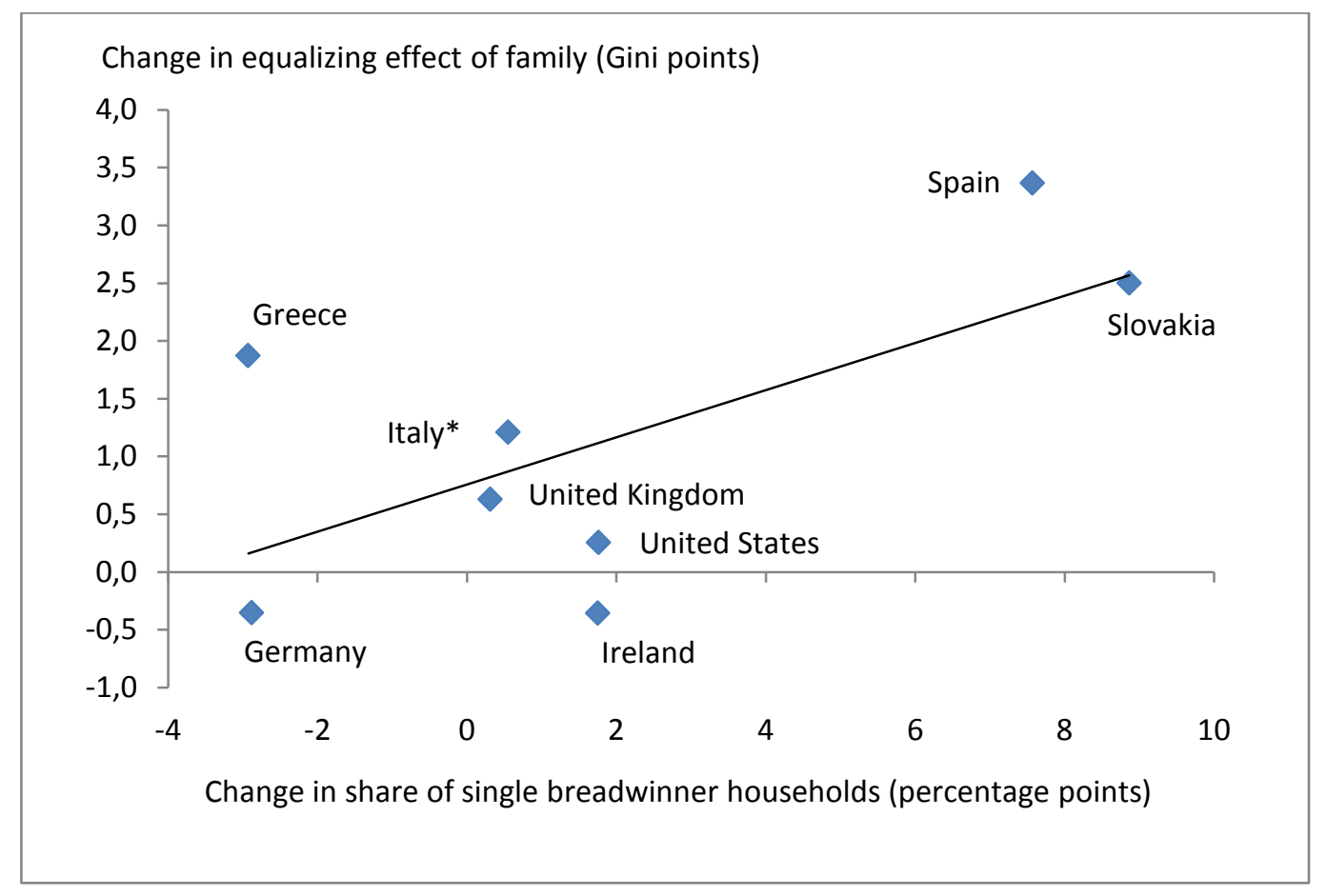

* Italy data are for 2008-10 and are net of tax and social security contributions in contrast to the data for other countries, which are in gross terms

Note: The precrisis trend is calculated over the 2000-2007 period using three data points, except for Italy (2000-08, three data points), the United Kingdom (1999-2007, three data points), and Slovakia (2004-07, two data points).

Source: Luxembourg Income Study Database, 1999-2010, http://www.lisdatacenter.org

In Greece, where the share of single breadwinner households was already very high before the recession, increased redistribution within households relative to trend appears to be related to an increase in average household size. Italy also shows a significant increase in household size relative to the continuation of the precrisis trend. This may reflect actions by families to reduce living costs through economies of scale, such as an increase of young working-age people continuing to live with their parents.

Ireland is a bit of an anomaly in that household size fell relative to trend. The explanation may have to do with the structure of the social safety net in Ireland, in particular the importance of means-tested benefits (see below). Because means-testing tends to involve assessing the economic situation of the whole household, not just the

\footnotetext{
${ }^{10}$. A single breadwinner household is defined as headed by a working-age individual living with a partner where the labor income of one partner exceeds the income of the other by a multiple of three. The shares are expressed relative to all households headed by a working-age individual living with a partner.
} 
individual, the employment status of other household members can affect the level of benefits. The availability of means-tested benefits may therefore discourage individuals from seeking economies of scale in living costs.

The role of the distribution of employment and incomes within households in mitigating the effect of the Great Recession on inequality has important implications for policy. It is widely recognized that increased female labor force participation tends to reduce the level of income inequality (see for example Harkness 2013). What this analysis suggests is that an additional benefit of high female employment is the enhanced resilience of household finances in recessions, which helps reduce the rise in earnings inequality that tends to result from rising unemployment, thereby reducing the burden on the government in supporting the incomes of those who have lost their jobs.

\section{THE ROLE OF THE SOCIAL SAFETY NET IN MITIGATING THE IMPACT OF THE GREAT RECESSION ON INCOME INEQUALITY}

Having considered the role of the family in supporting the standard of living of needy individuals, the following two sections consider the role of the state. In this section the income concept is expanded from earnings to total pre-tax income by including income from capital as well as social and private transfers. The next section adds direct taxes. The analysis continues to focus on individuals living in households with a working-age head.

Figure 6: Change in the Gini index between 2007 and 2010 using different income concepts

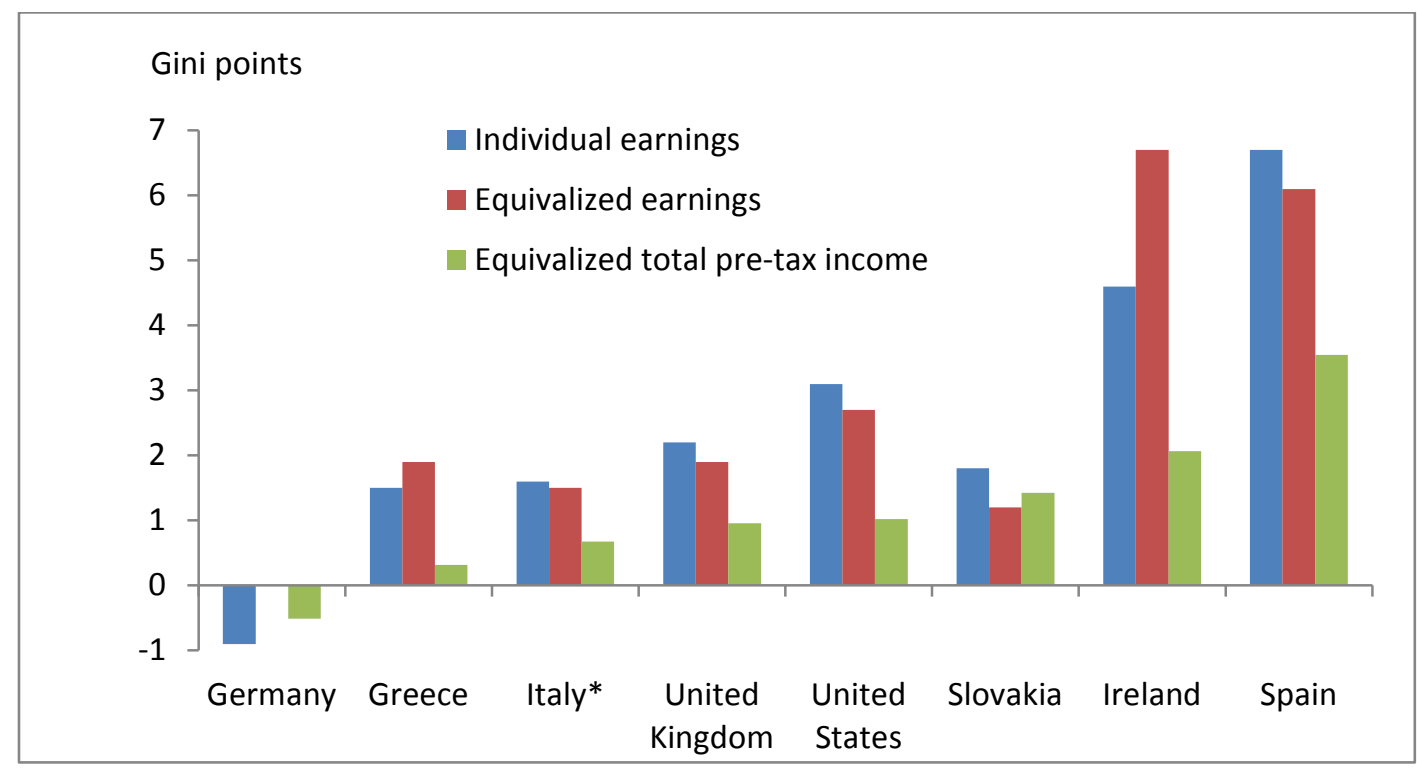

* Italy data are for 2008-10 and are net of tax and social security contributions in contrast to the data for other countries, which are in gross terms

Note: The precrisis trend is calculated over the 2000-2007 period using three data points, except for Italy (2000-08, three data points), the United Kingdom (1999-2007, three data points), and Slovakia (2004-07, two data points).

Source: Luxembourg Income Study Database, 1999-2010, http://www.lisdatacenter.org

To compare the impact of the family and of social transfers on the change in income inequality between 2007 and 2010, figure 6 shows the change in the Gini index using the three income concepts discussed so far. The blue bars show the change in inequality in individual earnings among the working-age population, which appeared in figure 3. The red bars show the change in inequality in equivalized income. The difference between the red and the blue bars corresponds to the change in the redistributive role of households shown in figure 4. Likewise, the difference between the green and the red bars can be thought of as representing primarily the role of social transfers in 
mitigating the rise in income inequality. ${ }^{11}$ In all countries that saw a fall in employment in the Great Recession, with the exception of Slovakia, the role of social transfers has been very significant.

Figure 7: Contributions of different income sources to change in inequality in equivalized total pre-tax income, 2007-10

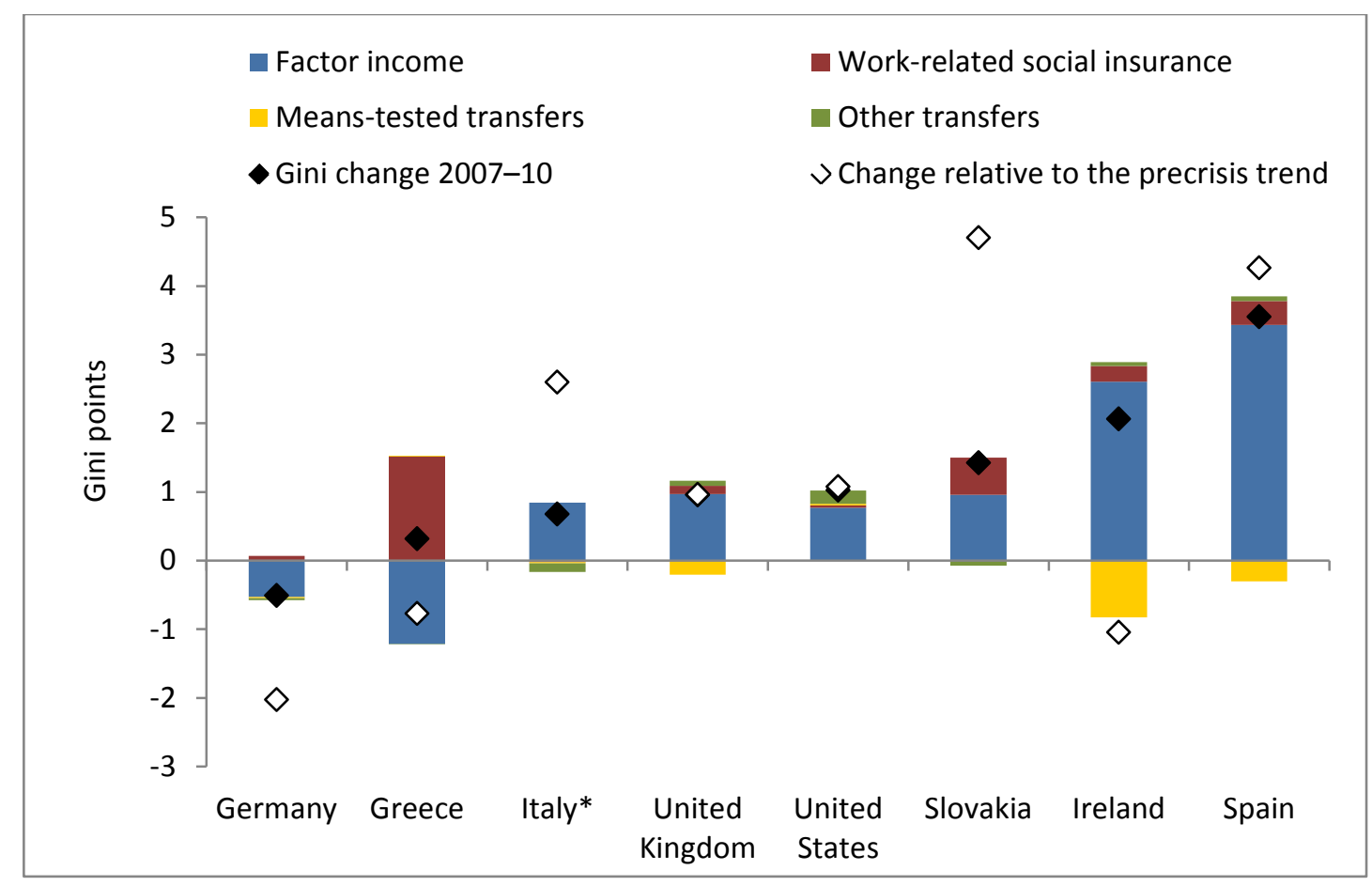

* Italy data are for 2008-10 and are net of tax and social security contributions in contrast to the data for other countries, which are in gross terms

Note: The precrisis trend is calculated over the 2000-2007 period using three data points, except for Italy (2000-08, three data points), the United Kingdom (1999-2007, three data points), and Slovakia (2004-07, two data points).

Source: Luxembourg Income Study Database, 1999-2010, http://www.lisdatacenter.org

To assess how different types of government transfers contribute to income inequality, figure 7 decomposes the green bars in figure 6 using a method of decomposing the Gini index by income source developed by R. I. Lerman and S. Yitzaki (1985). Lerman and Yitzaki showed that the contribution of a given income source to the Gini index on total income is the product of three factors. The first is the share of that income source in total income. The second is the inequality in the distribution of income from that source. The third factor captures the progressivity of the income from that source, that is, the extent to which the recipients of that income tend to be rich or poor when

\footnotetext{
${ }^{11}$. Capital income and private transfers, which are also included in total pre-tax income, had very little impact on the change in income inequality in the LIS data. Unfortunately, capital income is severely underreported in the LIS data. From the data available, capital income appears to have had a small equalizing effect between 2007 and 2010 in most countries in the sample. The true equalizing effect is likely to have been much larger, however, particularly when income from capital gains is included, which is not possible using LIS data. S. Ólafsson and A. S. Kristjánsson (2013) use tax returns data for Iceland to illustrate that capital income had a very large effect on income inequality, both as the Icelandic bubble inflated and once it burst.
} 
measured in terms of total income. So, for example, means-tested benefits may be distributed very unequally, but they have an equalizing impact on total income because they are highly progressive- they go mainly to the poor. ${ }^{12}$

Using this decomposition method, figure 7 shows the contributions of four sources of income to the Gini index on equivalized total pre-tax income. Factor income combines income from labor and capital. Work-related social insurance transfers relate to those public and private insurance programs where the level of benefit is tied to previous earnings and employment tenure. Means-tested transfers are those where eligibility is determined by need rather than by prior earnings or work history. The other transfers category includes universal public benefits and private transfers.

Figure 8: Decomposition of the contribution of employment-related social insurance to changes in inequality in equivalized total pre-tax incomes, 2007-10

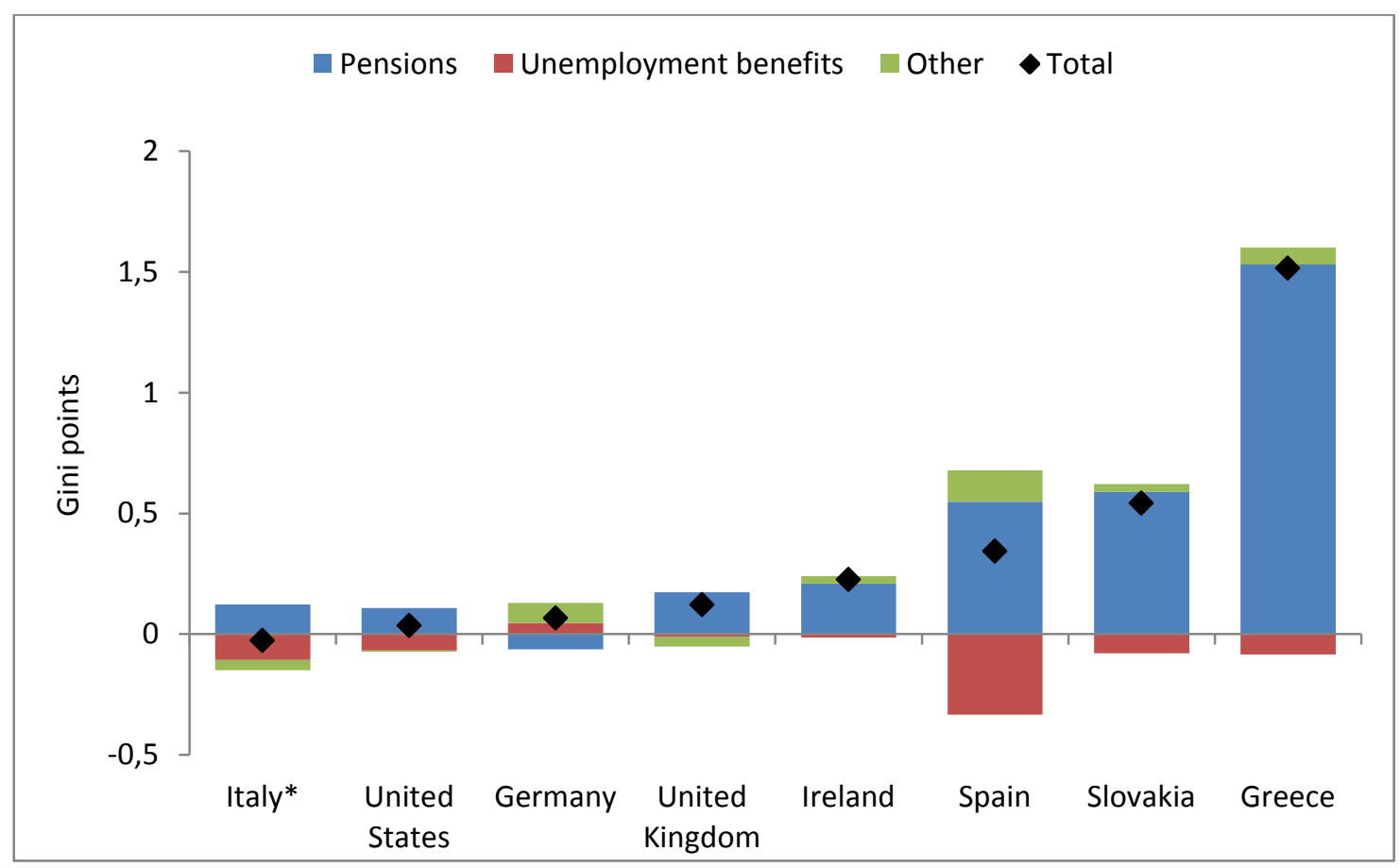

* Italy data are for 2008-10 and are net of tax and social security contributions in contrast to the data for other countries, which are in gross terms

Source: Luxembourg Income Study Database, 1999-2010, http://www.lisdatacenter.org

It is interesting to note the contrasting contributions of work-related social insurance benefits and means-tested transfers. With the exception of Slovakia and Germany, the share of both types of social transfers in total pre-tax income increased in all countries between 2007 and 2010. However, while the increase of means-tested benefits has tended to mitigate the rise in inequality in total pre-tax income, at least in those countries where they

\footnotetext{
${ }^{12}$. Formally, the Gini index on total income $G$ is given by:

where $S_{k}$ is the share of source $k$ in total income, $G_{k}$ is the Gini coefficient corresponding to the distribution of income from source $k$, and $R_{k}$ is the Gini correlation term given by: $\operatorname{cov}\left(\mathrm{y}_{\mathrm{k}}, \mathrm{F}\right) / \operatorname{cov}\left(\mathrm{y}_{\mathrm{k}}, \mathrm{F}_{\mathrm{k}}\right)$ where $\mathrm{F}$ is the cumulative distribution of total income, and $\mathrm{F}_{\mathrm{k}}$ is the cumulative distribution of income from source $k . R$ will equal $1(-1)$ when an income source is an increasing (decreasing) function of total income. $R$ will equal 0 when the income source is uniformly distributed.
} 
represent a meaningful component of the social safety net, the rising share of work-related social insurance benefits has had the opposite effect, exacerbating the rise in inequality in total pre-tax income. ${ }^{13}$

This is not to say that the rise in income inequality would have been smaller if social insurance programs such as work-related public pensions or work-related unemployment insurance did not exist. ${ }^{14}$ But it does highlight that payouts from insurance programs tied to prior work experience and earnings are regressive in the sense that the poorest households do not benefit from them as much as middle-class households, and their rising share in total income therefore increases inequality relative to social benefits that are distributed uniformly.

To investigate these two types of transfers in more detail, figures 8 and 9 decompose them further. Figure 8 shows that the contribution of work-related social insurance to rising inequality has been driven by pensions benefits. This may seem surprising given that the analysis is restricted to individuals living in households with a working-age head. In fact, in a number of countries the effective retirement age is below 65. Of the countries in the sample, the effective retirement age between 2007 and 2012 was relatively low in Slovakia and Greece. ${ }^{15}$

Greece stands out for the large contribution of pension benefits to the rise in income inequality between 2007 and 2010. LIS data suggests that the share of households with at least one member in retirement increased significantly in Greece, which led to an increase in the share of pensions in total pre-tax income. Because the distribution of work-related pensions is regressive (individuals with higher prior earnings receive higher pensions), a growing share of this source in total income will tend to increase income inequality.

The growing share of pensions in the income of families with a working-age head in Greece may reflect the response of families to rising joblessness mentioned in the previous section. Working-age individuals who have lost their earnings in the recession may have been forced to move in with their retired parents. But it may also reflect early retirement decisions. OECD analysis suggests that Greece is alone among the advanced economies in seeing an increase in the inactivity of older workers (those aged 55-64) relative to the population average (OECD 2013). Many older workers may have sought to take advantage of the very generous early retirement opportunities while they were still available in a number of professions in Greece.

Unemployment benefit schemes tied to prior work history had an equalizing effect between 2007 and 2010. Their contribution is typically very small, however, because they represent only a very small share in total disposable income in the survey, typically less than 2 percent. Although proportionately the share of this source in total income has increased significantly in all countries, its impact remains marginal in absolute terms.

Only in Ireland and Spain did unemployment benefits account for more than 2 percent of total disposable income in 2010, and the difference in the contributions from this income source to inequality in pre-tax income in these two countries is revealing. In both countries the share of unemployment benefits in total income almost doubled between 2007 and 2010. The main difference is that while unemployment benefits in Spain became effectively

\footnotetext{
${ }^{13}$. Note that this method of decomposing the Gini index is akin to an accounting exercise. It does not fully capture the general equilibrium effect on inequality of a given government policy. For example, changes to benefit eligibility will affect inequality not only directly, by changing the share of the benefit in total income and/or the inequality and/or progressivity of its distribution, but also indirectly via their effect on incentives to work and the resulting impact on the distribution of earnings.

${ }^{14}$. Within the decomposition framework used here, the impact on the Gini index of abolishing work-related social insurance would depend on how the resources freed up were used by the government and on the resulting effect of this change on the three factors $\left(S_{k}\right.$, $G_{k}$, and $R_{k}$ in the formula in footnote 11) determining the contributions of the remaining income sources. For example, if the money were used for means-tested benefits, the Gini index would fall, but if the money were used to reduce the rates of income tax, the Gini index would rise.
}

${ }^{15}$. See OECD, Statistics on Average Effective Age and Official Age of Retirement in OECD Countries, available at http://www.oecd.org/els/emp/ageingandemplovmentpolicies-statisticsonaverageeffectiveageofretirement.htm. 
much more progressive, in Ireland they remained broadly unrelated to total income and therefore had minimal impact on inequality. ${ }^{16}$

This difference may be related to the unequal duration of benefits in these two countries. The net replacement rate of unemployment benefits in Ireland is average by advanced economy standards (58.8 percent in 2009), but their duration is unusually long, stretching into the fifth year of an unemployment spell (OECD 2011b). Spain has a higher initial replacement rate (67.7 percent in 2009), but this falls substantially (to 23.5 percent) in the third year of unemployment. As the average unemployment duration increased between 2007 and 2010, unemployment benefit recipients in Spain but not in Ireland moved down the income ladder. In this situation unemployment benefits look more like aid to the poor than an insurance payout linked to past earnings. As such they have a much larger equalizing effect.

\section{Figure 9: Decomposition of the contribution of means-tested social transfers to changes in inequality in equivalized total pre-tax incomes, 2007-10}

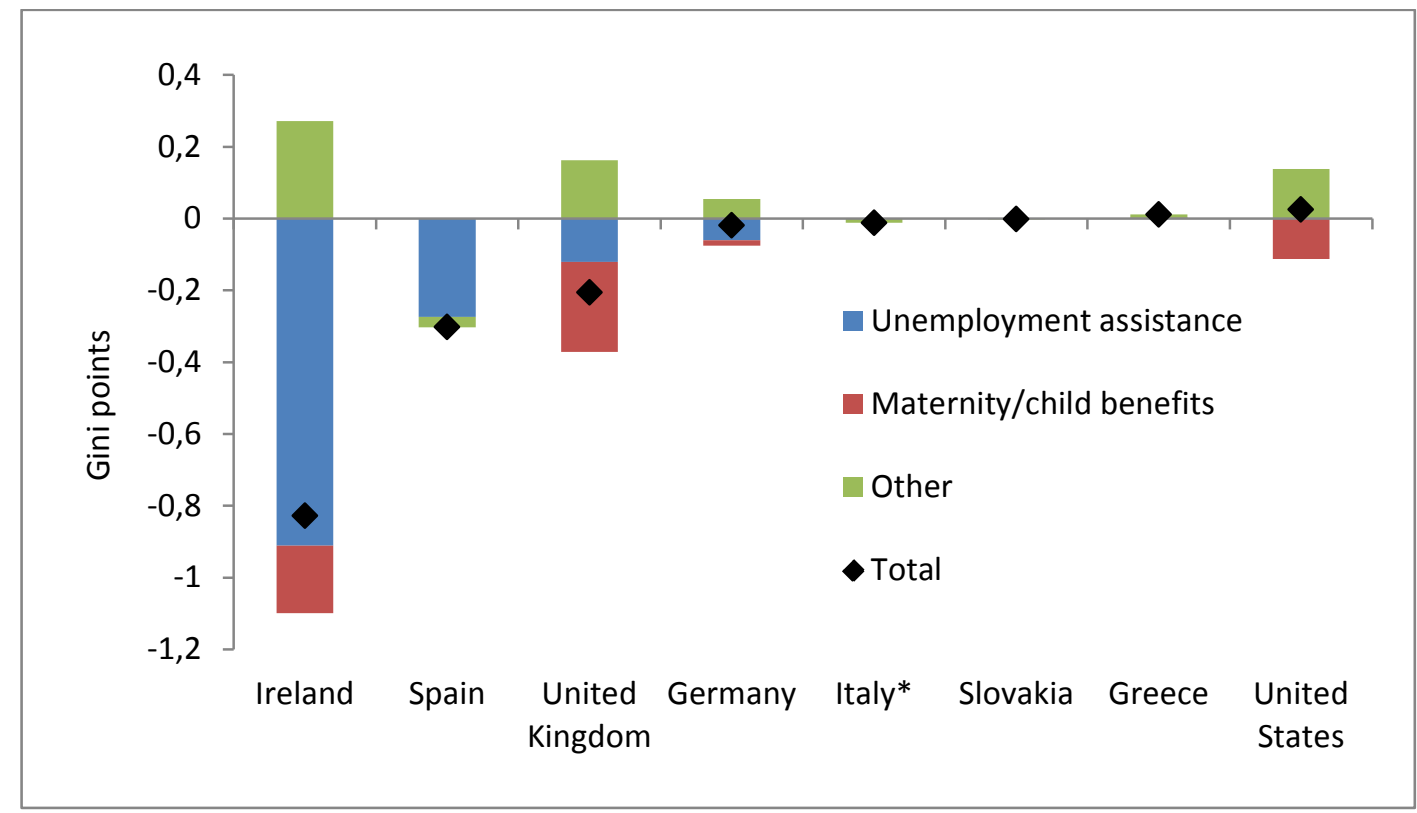

* Italy data are for 2008-10 and are net of tax and social security contributions in contrast to the data for other countries, which are in gross terms

Source: Luxembourg Income Study Database, 1999-2010, http://www.lisdatacenter.org

Turning to means-tested social assistance, figure 9 shows that, in countries most affected by the Great Recession and where social assistance forms a meaningful part of the social safety net, unemployment assistance and maternity or child assistance benefits contributed the most to reducing inequality in disposable income. Ireland stands out for the apparent effectiveness of its social assistance programs in responding to the impact of the Great Recession on income inequality. This is consistent with Ireland having one of the most generous social assistance programs with net income of single social assistance recipients excluding housing benefits reaching on average around 40 percent of median household income, compared to around 30 percent for Spain, 20 percent in the United Kingdom, and only around 7 percent in the United States (OECD 2011b).

\footnotetext{
${ }^{16}$. From the formula related to the Lerman and Yitzaki decomposition in footnote 11, it is clear that when the distribution of an income source is unrelated to the distribution of total income, the Gini correlation, $R_{k}$, will be close to zero, and the contribution to inequality in total income from this source will therefore also be close to zero.
} 
The impact on income inequality in different countries of different types of welfare programs suggests that benefits aimed at the most needy provide a much more potent means of offsetting growing earnings inequality caused by rising unemployment than benefits that are tied to prior earnings or work history. In times of economic prosperity means-tested benefits understandably raise concerns about their effect on incentives to work. In a deep recession, however, such concerns are more difficult to justify, and governments seeking to ensure that the burden of adjustment to macroeconomic shocks is shared fairly would do well to avoid cutting benefits targeted towards those in greatest need.

\section{THE ROLE OF INCOME TAX IN MITIGATING THE IMPACT OF THE GREAT RECESSION ON INCOME INEQUALITY}

In the last step of this analysis the income concept is expanded from total pre-tax income to total disposable income by including individuals' payments of taxes and social security contributions. The same method of decomposing the Gini index by income source introduced previously is used to assess the contributions of total pre-tax income and direct taxes to the change in inequality in disposable income between 2007 and 2010 (figure 10). Inequality in total disposable income changed little between 2007 and 2010 in most countries in the sample with the exception of Spain and Slovakia, which saw significant increases in inequality.

Figure 10: Contributions of total pre-tax income and taxes to change in inequality in disposable income, 2007-10

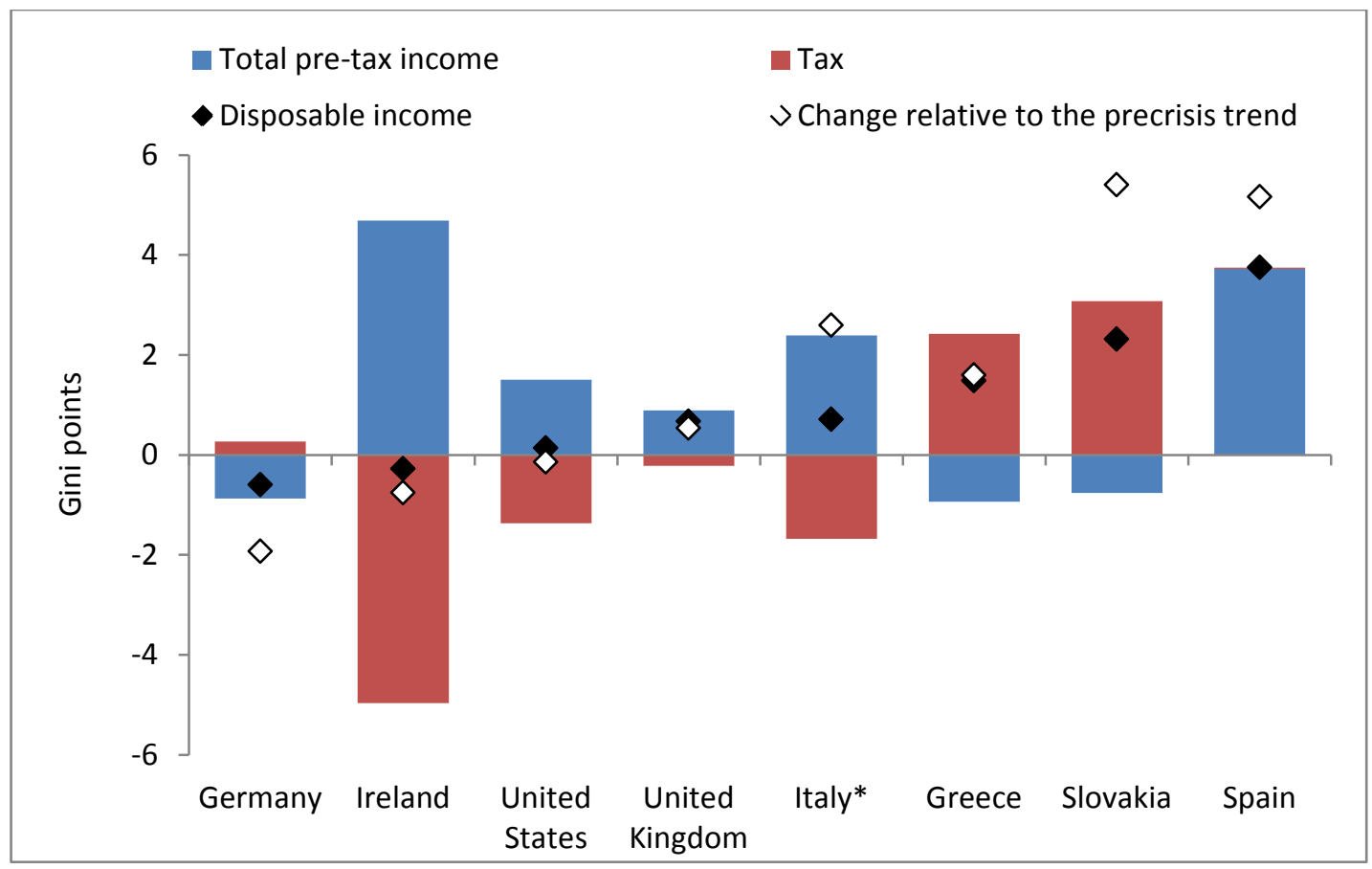

* Italy data are for 2008-10 and are in gross terms

Note: The precrisis trend is calculated over the 2000-2007 period using three data points, except for Italy (2000-08, three data points), the United Kingdom (1999-2007, three data points), and Slovakia (2004-07, two data points).

Source: Luxembourg Income Study Database, 1999-2010, http://www.lisdatacenter.org

The largest contributions from direct taxes to the change in inequality between 2007 and 2010 occurred in countries that significantly changed their income tax and social security systems. The Irish government, faced with collapsing 
revenues in the wake of the financial crisis and the bursting of its property bubble, introduced a new progressive tax on income in the 2009 budget, called an income levy, with the rates further increased in the emergency budget of $2009 .{ }^{17}$ As a result, the share of direct taxes in disposable income rose and became more progressive, completely offsetting the impact of greater inequality in pre-tax income on inequality in total disposable income.

Greece and Slovakia, by contrast, cut direct taxes between 2007 and 2010. The Slovak government responded to the Great Recession with a stimulus package in 2009 that temporarily but significantly lowered the basic income tax allowance and greatly reduced the social security contributions of the self-employed. ${ }^{18}$ The combined effect of these measures on income inequality has been the exact opposite of that seen in Ireland. The share of direct taxes in disposable income fell, primarily benefiting people near the middle of the income distribution rather than low earners whose earnings were largely tax-free even before the increase in the tax allowance. Moreover, selectively reducing social security contributions only for the self-employed made direct taxes significantly less progressive. A self-employed person ended up with a lower tax bill and higher disposable income than an employee on a similar pre-tax income. As a result direct taxes contributed significantly to increasing inequality in disposable incomes in Slovakia between 2007 and 2010.

The Greek government lowered the marginal tax rates on the middle two income tax brackets in 2008, shortly before the crisis. ${ }^{19}$ Together with the shrinking number of taxpayers in the top income tax brackets between 2007 and 2010, discussed above, these changes significantly reduced the share of direct taxes in total disposable income. As in Slovakia, the reduction in the share of (progressive) direct taxes in disposable income has increased inequality in disposable incomes.

It may seem surprising that total pre-tax income has an equalizing effect on disposable income in Slovakia and Greece, in contrast to all the other countries where unemployment rose in the Great Recession, particularly given that both countries saw a rise in inequality in total pre-tax income (figure 6). One should note, however, that in this decomposition framework, the inequality in income from a given source is only one of three factors influencing its contribution to overall inequality in total disposable income, the other two being the share of income from that source in total disposable income and the degree of progressivity in the income from that source. In the case of Greece and Slovakia, the effect that reducing the share of total pre-tax income in disposable income between 2007 and 2010 — a direct consequence of the tax cuts—had on inequality outweighed the effect of greater inequality in total pre-tax income.

Tax changes in the remaining countries in the sample were of a smaller magnitude. In general countries' direct taxes tended to mitigate the rise in inequality in the Great Recession. As falling employment reduced the tax base, the top earners picked up a larger share of the tax bill, making direct taxes effectively more progressive even without rate changes. The opposite seems to have happened in Germany, where employment rose.

The contrasting effect of tax increases and tax cuts on inequality in disposable income-as illustrated by the experience of Ireland, Slovakia, and Greece-has important policy implications. While taxes are often changed primarily with macroeconomic objectives in mind, the effect on income distribution should not be overlooked. In general, increases in direct taxes will tend to have an equalizing effect, while tax cuts will tend to exacerbate income inequality. That is not to say that tax cuts are not an appropriate means of stimulating the economy or that

\footnotetext{
${ }^{17}$. See Budget 2009 documents for the Republic of Ireland, available at http://www.budget.gov.ie/Budgets/2009/2009.aspx.

${ }^{18}$. See the Stability Programme of the Slovak Republic for 2008-12, available at http://www.finance.gov.sk/en/Documents/1 Adresar redaktorov/Savov/PS2008 EN final.pdf.
}

${ }^{19}$. See IMF Article IV consultation staff report on Greece in 2007, available at http://www.imf.org/external/pubs/ft/scr/2008/cr08148.pdf. 
fiscal consolidation measures should happen primarily via increases in direct taxes. The case studies do, however, suggest that a given macroeconomic objective can be achieved with very different distributional outcomes.

\section{CONCLUSIONS AND OUTLOOK}

The eight advanced economies analyzed here display considerable diversity in the effect of the Great Recession on income inequality and the ability of families and the state to mitigate its impact through redistribution within households and through public benefit programs and the tax system. Inequality in total disposable income has changed little between 2007 and 2010 in most countries in the sample with the exception of Spain and Slovakia, which saw significant increases in inequality.

In general the effect of the Great Recession on the distribution of earnings among those who remained employed appears to have been limited in most countries, with the notable exception of Greece where earnings inequality fell in response to severe cuts to public sector wages. The Greek experience suggests that consolidation measures and structural reforms aimed at removing special privileges of certain professions and sectors can on balance contribute to equality of incomes.

The fall in employment seen in most countries in the sample between 2007 and 2010 significantly increased inequality in earnings among the working-age population in those countries most affected. Given the significance of earnings in total income, developments in employment matter greatly for inequality outcomes. The experience of Germany suggests that policies designed to reduce the impact of a negative economic shock on unemployment can go a long way to mitigating the rise in earnings inequality in a recession.

Greater redistribution of earnings within households relative to the precrisis trend has gone some way to mitigating the effect of the Great Recession on inequality. In some countries this was driven by an increase in the share of single breadwinner households, presumably caused in many cases by one partner losing his or her job. This suggests that policies to increase female labor force participation can play an important role in buttressing the resilience of household finances and mitigating the effect of unemployment on income inequality in future recessions.

With few exceptions government policies—-the social safety net and direct taxes—had a much larger mitigating impact on income disparities, with inequality in disposable incomes little changed between 2007 and 2010 in most countries. The marginal impact of means-tested social assistance benefits, which are highly progressive, in mitigating the rise in inequality has been larger than that of work-related social insurance programs, which tend to be regressive.

Existing direct taxes have tended to have an equalizing effect in most countries, as the shrinking tax base has increased their effective progressivity. Ireland illustrates that raising direct tax rates can make a significant contribution to reducing inequality, while Slovakia and Greece illustrate the opposite-tax cuts tend to make the distribution of disposable incomes more unequal.

The impact of the social safety net and direct taxes on the change in inequality in disposable incomes in the Great Recession highlights the importance of the precise nature of the fiscal policy mix in targeting a particular macroeconomic objective, such as stimulating the economy or consolidating public finances. Governments seeking to spread the burden of adjustment fairly among their citizens should keep in mind that different combinations of policies can have very different distributive effects.

The results presented here make it possible to attempt at least a qualitative statement about the likely trend in income inequality since 2010 based on subsequent economic developments. With the exception of Germany, the employment to working-age population ratio has remained broadly stable, in some countries following a decline 
before 2010 (Italy, the United Kingdom, and the United States) or continuing to decline (Greece, Spain, Slovenia, and Ireland). Given the importance of earnings in total income and the importance of employment in driving changes in earnings inequality, a significant fall in income inequality since 2010 seems unlikely in most countries in the sample.

The other major development seen since 2010 in most advanced economies has been fiscal austerity. Clearly not all consolidation measures need to increase income inequality, and the precise distributional impact in any given country will depend on the mix of policies implemented. In general, however, past experience suggests that consolidation episodes tend to be associated with rising income inequality (see for example J. Woo et. al. 2013). It therefore seems more likely than not that income inequality has increased further since 2010 in most of the countries analyzed in this study. ${ }^{20}$

\section{REFERENCES}

Atkinson, A. B., and A. Brandolini. 2006. From Earnings Dispersion to Income Inequality. In Inequality and Economic Integration, eds. F. Farina and E. Savaglio. London: Routledge.

Atkinson, A. B., and T. Piketty. 2007. Top Incomes Over the 20th Century. London: Oxford University Press.

Cowell, F. A. 2011. Measuring Inequality. London: Oxford University Press.

Harkness, S. 2013. Women's Employment and Household Income Inequality. In Income Inequality: Economic Disparities and the Middle Class in Affluent Countries, eds. J. C. Gornick and M. Jäntti. Palo Alto, CA: Stanford University Press.

Lerman, R. I., and S. Yitzhaki. 1985. Income Inequality Effects by Income Source: A New Approach and Applications to the United States. Review of Economics and Statistics 67, no. 1: 151-56.

Luxembourg Income Study (LIS) Database, http://www.lisdatacenter.org (multiple countries; 1999-2010). Luxembourg: LIS.

OECD (Organization for Economic Cooperation and Development). 2011a. Divided We Stand: Why Inequality Keeps Rising. Paris. Available at http://dx.doi.org/10.1787/9789264119536-en (accessed on December 5, 2013).

OECD. 2011b. Income Support for the Unemployed: How Well Has the Safety-Net Held Up During the "Great Recession”? In OECD Employment Outlook 2011. Paris. Available at http://dx.doi.org/10.1787/empl outlook-2011-3-en (accessed on December 5, 2013).

OECD. 2013. All in it together? The experience of different labour market groups following the crisis. In OECD Employment Outlook 2013. Paris. Available at http://dx.doi.org/10.1787/empl outlook-2013-5-en (accessed on December 5, 2013).

Ólafsson, S., and A. S. Kristjánsson. 2013. Income Inequality in Boom and Bust: A Tale from Iceland’s Bubble Economy. In Income Inequality: Economic Disparities and the Middle Class in Affluent Countries, eds. J.C. Gornick and M. Jäntti. Palo Alto, CA: Stanford University Press.

Wagner, Gert G., Joachim R. Frick, and Jürgen Schupp. 2007. The German Socio-Economic Panel Study (SOEP) - Scope, Evolution and Enhancements. Schmollers Jahrbuch 127, no. 1, 139-169. http://schmollersjahrbuch.diw.de/schmollersjahrbuch/webcontent/2007/Wagner\%20et\%20al.pdf

Woo, J.; Bova, E.; Kinda, T.; and Y. S. Zhang. 2013. Distributional Consequences of Fiscal Consolidation and the Role of Fiscal Policy: What Do the Data Say? IMF Working Paper 13/195. Washington: International Monetary Fund.

\footnotetext{
${ }^{20}$. The recovery in asset prices, not analyzed here, is another factor that has probably contributed to rising inequality since 2010 in most countries outside the euro area periphery.
} 


\section{APPENDIX A: THE DATASET}

The analysis in this Policy Brief uses income data from the Luxembourg Income Study (LIS). The LIS team acquires reliable microdata from national household income surveys, carefully harmonizes and standardizes them, and makes them available for analysis through a secure server to maintain data privacy and confidentiality. The LIS has data on 39 advanced- and middle-income countries at about three- to five-year intervals.

Because the focus of this analysis is the period of the Great Recession and because more recent data are not yet available, the analysis is restricted to two survey years, 2007 and 2010, although previous surveys are used to calculate precrisis trends. The 2007-10 period captures the Great Recession and the immediate effects of the fiscal stimulus measures put in place by many advanced economies to mitigate its impact. It does not cover developments since 2010, such as the flaring up of the sovereign debt crisis in Europe, the euro area's second dip into recession, or the wave of fiscal austerity that swept over the continent. Table A1 lists the countries in the sample and the number of households and individuals contained in each survey.

Using survey data to analyze income inequality has a number of advantages relative to the main alternative, which is data on income shares obtained from tax returns. Most importantly, survey data aim to capture the entire income distribution, not just those people whose income exceeds the tax allowance threshold. Household surveys also contain information on disposable income, including taxes, social security contributions, and nontaxable social benefits that are not contained in tax return data. Disposable income arguably better captures people's command over resources than taxable income. Moreover, the available microdata make a much more detailed analysis of the drivers of inequality possible.

There are, however, important shortcomings of survey data that one should keep in mind when interpreting the results presented here. Survey data are based on only a small sample of the population. Although the collection of survey information is carefully designed to be as representative of the population as possible, and the data collected is weighted to ensure key demographic characteristics are reflected as accurately as possible, some of the changes in key statistics between surveys, such as the Gini index or changes in employment, may reflect sampling variation rather than true changes in the underlying population.

To illustrate this problem, figure A1 compares the change between 2007 and 2010 in the employment to workingage population ratio in the LIS data with OECD data based on national Labor Force Surveys (LFS), which are specifically designed to accurately capture key aspects of the labor market. There are some significant discrepancies between the two surveys in some countries, particularly in Greece, where the LIS data have a higher estimate of the employment rate in 2007 and a lower one in 2010 than LFS data. Nevertheless the discrepancies do not seem so large as to render the LIS data useless for analyzing the impact of the Great Recession on income inequality.

Another problem with survey data is that, despite best efforts, it generally suffers from undersampling of low incomes and underreporting of high incomes. We can illustrate the problem by comparing top income shares from data based on tax returns with top income shares in the LIS data. Figure A2 below makes use of the World Top Incomes Database (WTID). ${ }^{21}$ It compares the share of market income (labor income, capital income, and private transfers) going to the top 1 percent of tax reporting units ${ }^{22}$ in the two datasets covering the period of the past 20 to 40 years, depending on the country. Those country-year observations that appear in this Policy Brief are

\footnotetext{
${ }^{21}$. The WTID data is available at http://topincomes.g-mond.parisschoolofeconomics.eul. See Atkinson and Piketty (2007).

${ }^{22}$. The tax reporting unit in some countries is the individual, while in others it is the household/family. For the purpose of this figure, the household is treated as the unit of analysis in the LIS for country-years where the tax reporting unit in the WTID data is the household, and the individual is used as the unit of analysis in the LIS for country-years where the tax reporting unit is the individual.
} 
highlighted. The chart suggests that underreporting of high incomes is particularly severe in the United States, the United Kingdom, and Ireland. But there are also many points above the 45 degree line. For these country-years, undersampling of low incomes may be a bigger problem than underreporting of high ones. However, discrepancies may also arise for other reasons, such as underreporting of certain sources of income such as income from capital.

The implication for the results presented here is that they are unlikely to fully reflect the impact of the Great Recession on the very rich. This is significant because the WTID data suggests that the top 1 percent are different. Not only have they seen a much faster rise in their share of income over the past 30 years in many countries, they have also been hit harder by the Great Recession than those occupying the 90th to 99th percentile of the income distribution (figure A3). This probably reflects developments in capital incomes, such as incomes from interest and dividends, which accrue disproportionately to richer households.

Table A1: Unweighted number of observation in the LIS data

\begin{tabular}{lcccc}
\hline & \multicolumn{2}{c}{ Households } & \multicolumn{2}{c}{ Individuals } \\
& $\mathbf{2 0 0 7}$ & $\mathbf{2 0 1 0}$ & $\mathbf{2 0 0 7}$ & $\mathbf{2 0 1 0}$ \\
\hline Germany & 10,921 & 12,146 & 24,999 & 26,952 \\
Greece & 6,504 & 6,029 & 16,869 & 15,067 \\
Ireland & 5,247 & 4,333 & 12,551 & 11,005 \\
Italy* & 7,977 & 7,951 & 19,907 & 19,836 \\
Slovakia & 5,450 & 5,200 & 16,546 & 15,335 \\
Spain & 13,014 & 13,109 & 35,970 & 34,756 \\
United Kingdom & 24,977 & 25,350 & 56,926 & 57,928 \\
United States & 75,872 & 75,188 & 206,404 & 204,983 \\
\hline
\end{tabular}

LIS = Luxembourg Income Study

* Italy data are for 2008-10

Source: Luxembourg Income Study Database, 1999-2010, http://www.lisdatacenter.org

Figure A1: Change in employment to working age population ratio, 2007-10 


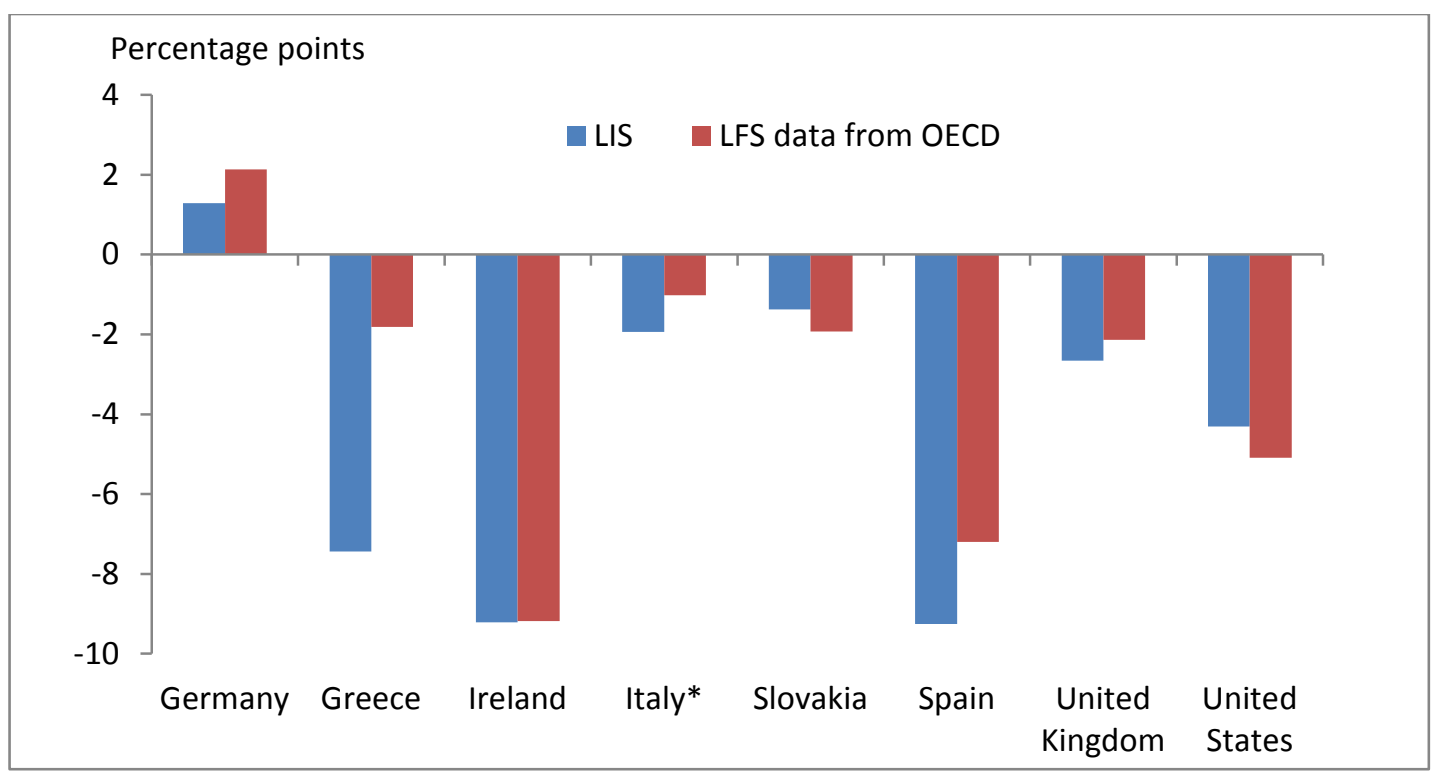

LIS = Luxembourg Income Study; LFS = Labor Force Survey; OECD = Organization for Economic Cooperation and Development

* Italy data are for 2008-10

Sources: Luxembourg Income Study Database, 1999-2010, http://www.lisdatacenter.org; OECD Labor Force Surveys, http://www.oecd.org/emplovment/emp/onlineoecdemplovmentdatabase.htm\#unr

Figure A2: Comparison of top income shares, 2007-10

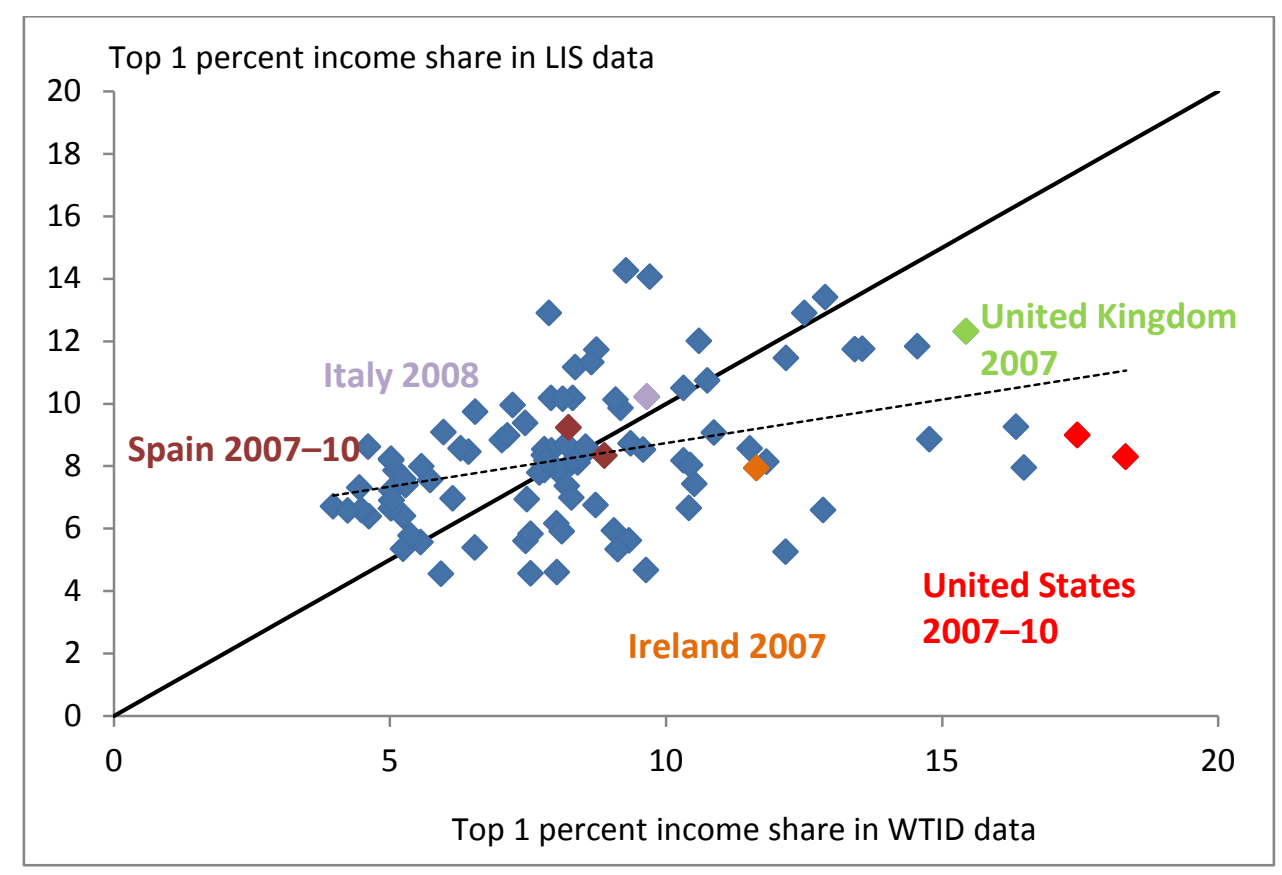

LIS = Luxembourg Income Study; WTID = World Top Incomes Database

Sources: Luxembourg Income Study Database, 1999-2010, http://www.lisdatacenter.org; World Top Incomes Database, http://topincomes.gmond.parisschoolofeconomics.eu/ 
Figure A3: Change in top income shares in WTID data, 2007-10

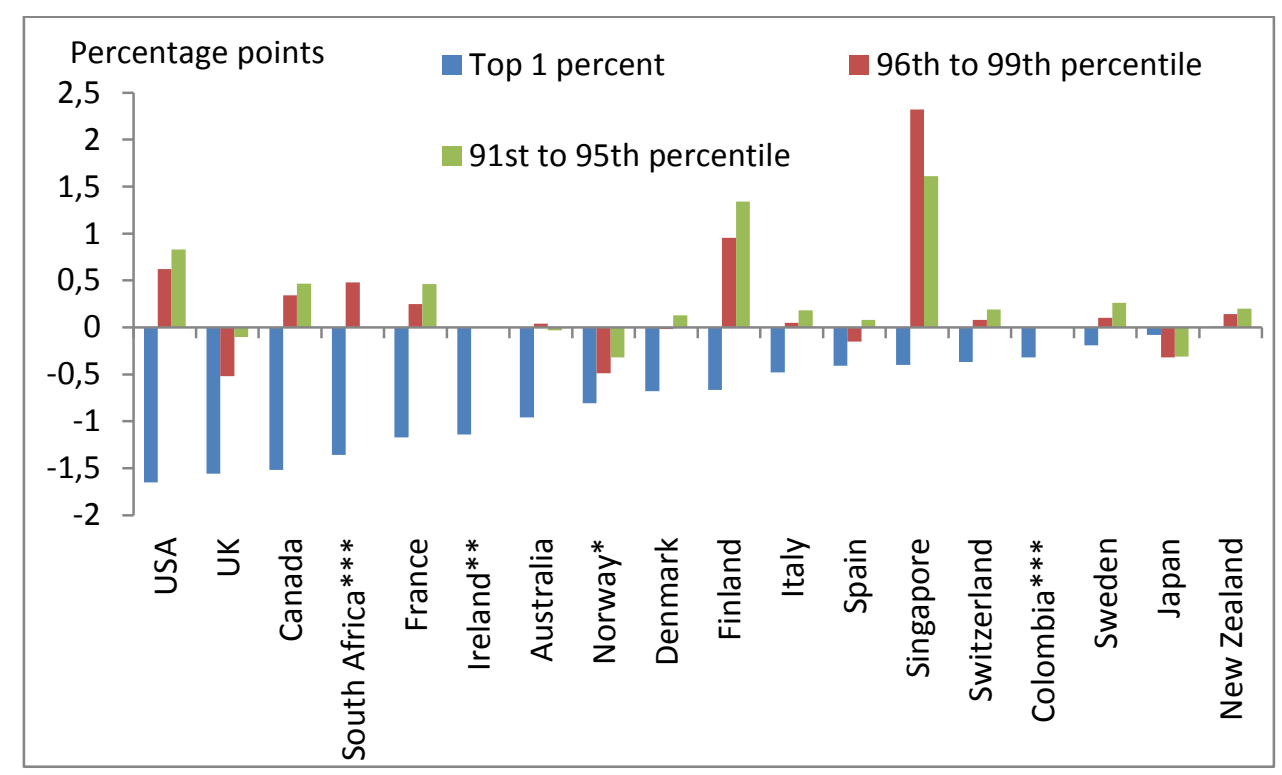

WTID = World Top Incomes Database

* Norway data are for 2007-08.

** Ireland data are available for only the top 1 percent and the top 10 percent. The change in the share of the 91st-99th percentile was +0.6 percentage points.

*** Colombia data are available for only the top 1 percent, and South Africa data for only the top 1 percent and 5 percent.

Source: World Top Incomes Database, http://topincomes.g-mond.parisschoolofeconomics.eu/ 